\title{
Aceh, Masalah Narkoba Dan Pelacuran Dalam Sorotan: Sebuah Tinjauan Awal
}

\section{Fajri M Kasim}

Alumnus Universitas Kebangsaan Malaysia dan dosen Universitas Malikussaleh Aceh, Indonesia

\section{Abstract}

Field data obtained in five districts / cities in Aceh can be represented as a sample of all regions in Aceh. The cities that are used as primary data references are Kota Lhokseumawe, Banda Aceh, Meulaboh, Takengon, and Langsa City assuming Lhokseumawe and Langsa represent Coastal Aceh, Banda Aceh Aceh Government Center, Meulaboh representing the south west Aceh region and Takengon representing the central Aceh region. It is increasingly clear that Narcotics and Prostitution Practices have become Aceh's problems that must be addressed and overcome by the government and the community in a continuous and simultaneous and comprehensive manner so that they do not become widespread in the future.

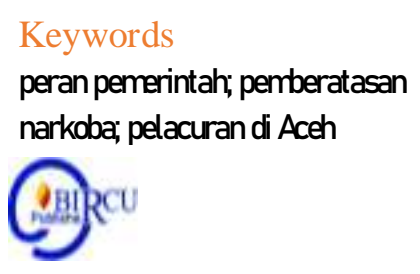

\section{Pendahuluan}

Narkoba dan Praktek Pelacuran telah menjadi masalah yang dihadapi segala bangsa, peredaran Narkoba dan Praktek Pelacuran seperti tidak ada hentinya meski telah bertahuntahun, berkali-kali dan beramai-ramai diberantas. Penawaran pun akan selalu ada untuk mencari dan memenuhi permintaan pasar. Hal ini terdengar seperti sesuatu yang lumrah dan tidak perlu diperdebatkan lagi. Tetapi jika dianalisis lebih dalam, dampak yang dihasilkan dari penggunaan zat terlarang ini bukan hal kecil. Efek samping penggunaan narkoba dapat menyebabkan kerusakan saraf, bahkan dapat berdampak pada kematian begitu pula dengan Pelacuran dapat merusak sendi kehidupan bermasyarakat dan penyakit yang mematikan. Mengonsumsi Narkoba dan Praktek Pelacuran memiliki efek yang berbeda berdasarkan jenis dan kadar yang dikonsumsi serta dampak sosial lainya.

Masyarakat Aceh pada dasarnya identik dengan salah satu Narkoba yaitu ganja. Akan tetapi kedekatan masyarakat Aceh dengan ganja tidak sepenuhnya dapat dimaknai sebagai sesuatu yang negative. Karena maksud dan tujuan dari penggunaan ganja oleh masyarakat Aceh pada zaman dulu berbeda dengan maksud dan tujuan penggunaannya sekarang. Ganja saat ini sudah lebih banyak disalahgunakan daripada diambil manfaat yang didapat darinya. Penyalahgunaan ganja ini kemudian menjadikan ganja termasuk dalam salah satu barang terlarang yang harus diperhatikan, dikontrol bahkan diberantas eksistensinya.

Peredaran dan penggunaan Narkoba saat ini tentu tidak dapat disamakan dengan zaman dulu, dengan semakin canggihnya teknologi, memungkinkan pengiriman barang datang dari mana saja ke tempat tujuan. Aceh sendiri menjadi salah satu sasaran dari peredaran Narkoba, bukan hanya ganja saja yang beredar tetapi juga Narkoba jenis lain seperti sabu. Ironis memang mengingat wilayah yang didominasi masyarakat muslim, yang hidup dengan hukum 
syariat dalam konstitusi daerahnya, justru terjajah moralnya menggunakan Narkoba. Ancaman besar tentu datang kepada generasi muda Aceh yang kelak meneruskan perjuangan para pendahulunya. Selain anacaman narkoba di Aceh ancaman yang lainya teman dari barang ini adalah perilaku seks beresiko atau pelacuran yang juga mulai marak di Aceh sekarang ini.

\section{Kajian Pustaka}

Penelitian ini dijadwalkan berlangsung selama dua tahun dengan laporan untuk setiap tahunnya. Penelitian rencananya akan dimulai dengan mengumpulkan data dari kasus yang didapat dari tahun 2014. Data ini kemudian akan dilengkapi dengan data terbaru pada tahun 2015 untuk kemudian melihat bagaimana dinamika perkembangan peredaran Narkoba dan Praktek Pelacuran yang ada di Aceh antara tahun 2014 sampai 2015. Perbandingan antara keduanya penting untuk melihat apakah permintaan dan peredaran Narkoba dan Praktek Pelacuran di Aceh mengalami peningkatan atau penurunan.

Sejauh ini peneliti tidak banyak menemukan literature yang sekiranya relevan dengan kajian yang akan diambil oleh Peneliti. Untuk itu peneliti juga akan menjadikan penelitian ini sebagai landasan untuk penelitian berikutnya yang mungkin akan dikembangkan dari penelitian ini. Penelitian ini juga tentunya dapat dijadikan panutan bagi peneliti-peneliti lain yang memiliki minat dalam bidang kajian yang sama sehingga dapat memperkaya literature yang dapat digunakan untuk melakukan kajian ini.

Adapun Gambaran singkat mengenai Narkoba (singkatan dari Narkotika, Psikotropika dan Bahan Adiktif berbahaya lainnya) sebenarnya digunakan untuk pengobatan dan penelitian. Tetapi karena berbagai alasan mulai dari keinginan untuk coba-coba, ikut trend/gaya, lambang status sosial, ingin melupakan persoalan, dan lain-lain. Maka Narkoba kemudian disalahgunakan. Narkoba adalah bahan/zat yang jika dimasukan dalam tubuh manusia, baik secara oral/diminum, dihirup, maupun disuntikan, dapat mengubah pikiran, suasana hati atau perasaan, dan perilaku seseorang. Narkoba dapat menimbulkan ketergantungan (adiksi) fisik dan psikologis. Narkotika merupakan zat atau obat yang berasal dari tanaman atau bukan tanaman, baik sintetis maupun semi sintetis yang dapat menyebabkan penurunan atau perubahan kesadaran, hilangnya rasa nyeri dan dapat menimbulkan ketergantungan (Undang-Undang No. 22 tahun 1997). Adapun Jenis Narkotika adalah : a. Tanaman papaver, opium mentah, opium masak (candu, jicing, jicingko), opium obat, morfina, kokaina, ekgonina, tanaman ganja, dan damar ganja. b. Garam-garam dan turunan-turunan dari morfina dan kokaina, serta campuran-campuran dan sediaan-sediaan yang mengandung bahan tersebut di atas. c. Psikotropika adalah zat atau obat, baik alamiah maupun sintetis bukan narkotika, yang berkhasiat psikoaktif melalui pengaruh selektif pada susunan saraf pusat yang menyebabkan perubahan pada aktivitas mental dan perilaku.(Undang-Undang No. 5/1997).

Zat yang termasuk psikotropika antara lain: Sedatin, Rohypnol, Magadon, Valium, Mandarax, Amfetamine, Fensiklidin, Metakualon, Metifenidat, Fenobarbital, Flunitrazepam, Ekstasi, Shabu-shabu, LSD (Lycergic Alis Diethylamide), dsb. Bahan Adiktif berbahaya lainnya adalah bahan-bahan alamiah, semi sintetis maupun sintetis yang dapat dipakai sebagai pengganti morfina atau kokaina yang dapat mengganggu sistim syaraf pusat.

Jenis Narkoba menurut efeknya dibedakan menjadi tiga: a. Depresan, yaitu menekan sistem sistem syaraf pusat dan mengurangi aktifitas fungsional tubuh sehingga pemakai merasa tenang, bahkan bisa membuat pemakai tidur dan tak sadarkan diri. Bila kelebihan dosis bisa mengakibatkan kematian. Jenis Narkoba depresan antara lain opioda, dan berbagai turunannya seperti morphin dan heroin. Contoh yang populer sekarang adalah Putaw. b. Stimulan, yaitu merangsang fungsi tubuh dan meningkatkan kegairahan serta kesadaran. Jenis stimulan: Kafein, Kokain, Amphetamin. Contoh yang sekarang sering dipakai adalah Shabu- 
shabu dan Ekstasi. c. Halusinogen Efek utamanya adalah mengubah daya persepsi atau mengakibatkan halusinasi. Halusinogen kebanyakan berasal dari tanaman seperti mescaline dari kaktus dan psilocybin dari jamur-jamuran. Selain itu ada juga yang diramu di laboratorium seperti LSD. Yang paling banyak dipakai adalah marijuana atau ganja.

\subsection{Dampak penyalahgunaan Narkoba}

Bila Narkoba digunakan secara terus menerus atau melebihi takaran yang telah ditentukan akan mengakibatkan ketergantungan. Kecanduan inilah yang akan mengakibatkan gangguan fisik dan psikologis, karena terjadinya kerusakan pada sistem syaraf pusat (SSP) dan organ-organ tubuh seperti jantung, paru-paru, hati dan ginjal. Dampak penyalahgunaan Narkoba pada seseorang sangat tergantung pada jenis Narkoba yang dipakai, kepribadian pemakai dan situasi atau kondisi pemakai. Secara umum, dampak kecanduan Narkoba dapat terlihat pada fisik, psikis maupun sosial seseorang.

Dampak Fisik: 1). Gangguan pada system syaraf (neurologis) seperti: kejang-kejang, halusinasi, gangguan kesadaran, kerusakan syaraf tepi. 2). Gangguan pada jantung dan pembuluh darah (kardiovaskuler) seperti: infeksi akut otot jantung, gangguan peredaran darah. 3). Gangguan pada kulit (dermatologis) seperti: penanahan (abses), alergi, eksim. 4). Gangguan pada paru-paru (pulmoner) seperti: penekanan fungsi pernapasan, kesukaran bernafas, pengerasan jaringan paru-paru. 5). Sering sakit kepala, mual-mual dan muntah, murus-murus, suhu tubuh meningkat, pengecilan hati dan sulit tidur. 6).Dampak terhadap kesehatan reproduksi adalah gangguan pada endokrin, seperti: penurunan fungsi hormon reproduksi (estrogen, progesteron, testosteron), serta gangguan fungsi seksual. 7). Dampak terhadap kesehatan reproduksi pada remaja perempuan antara lain perubahan periode menstruasi, ketidakteraturan menstruasi, dan amenorhoe (tidak haid). 8). Bagi pengguna Narkoba melalui jarum suntik, khususnya pemakaian jarum suntik secara bergantian, risikonya adalah tertular penyakit seperti hepatitis B, C, dan HIV yang hingga saat ini belum ada obatnya. 9). Penyalahgunaan Narkoba dan Praktek Pelacuran bisa berakibat fatal ketika terjadi Over Dosis yaitu konsumsi Narkoba dan Praktek Pelacuran melebihi kemampuan tubuh untuk menerimanya. Over dosis bisa menyebabkan kematian.

Dampak Psikis: 1). Lamban kerja, ceroboh kerja, sering tegang dan gelisah. 2). Hilang kepercayaan diri, apatis, pengkhayal, penuh curiga. 3). Agitatif, menjadi ganas dan tingkah laku yang brutal. 4). Sulit berkonsentrasi, perasaan kesal dan tertekan. 5). Cenderung menyakiti diri, perasaan tidak aman, bahkan bunuh diri.

Dampak Sosial: 1). Gangguan mental, anti-sosial dan asusila, dikucilkan oleh lingkungan. 2). Merepotkan dan menjadi beban keluarga. 3). Pendidikan menjadi terganggu, masa depan suram Dampak fisik, psikis dan sosial berhubungan erat. Ketergantungan fisik akan mengakibatkan rasa sakit yang luar biasa (sakaw) bila terjadi putus obat (tidak mengkonsumsi obat pada waktunya) dan dorongan psikologis berupa keinginan sangat kuat untuk mengkonsumsi (bahasa gaulnya sugest). Gejata fisik dan psikologis ini juga berkaitan dengan gejala sosial seperti dorongan untuk membohongi orang tua, mencuri, pemarah, manipulatif, dan lain-lain.

\subsection{Praktek Pelacuran}

Praktek Pelacuran ialah tindakan seksual yang dilakukan sebelum dan sesudah (menikah). Praktek Pelacuran ini biasanya dilakukan oleh lelaki hidung belang dan wanita yang sudah terjun kedunia hitam (jual diri untuk mendapat kenikmatan seks sesaat dan keuntungan finansial bagi perempuan). Menurut Koentjoro (1988 dan 1989) hal ini diakibatkan oleh: (a) kontrol sosial masyarakat menjadi melemah, (b) toleransi terhadap pelacuran dan perselingkuhan meningkat, (c) aspirasi material masyarakat meningkat. 
Menurut Koentjoro (1998) di daerah penghasil pelacur: (a) menjadi pelacur itu rewarding, (b) pelacur yang berhasil menjadi model sosialisasi, (c) Motif melacur tidak selalu datang dari si anak, namun dapat terjadi datang dari orangtua, suami. Anak, suami, orangtua pada umumnya di dominasi oleh aspirasi material yang sangat tinggi, dan telah mendapat pengaruh dari instigator, (d) disinyalir ada bantuan khusus dari mucikari/sponsor/instigator untuk menciptakan keterikatan sekaligus social marketing, dengan cara memberi pinjaman untuk membangun rumah dengan gaya modern dan melengkapi perabot rumah tangga, (e) sosialisasi pelacur pada anak terjadi sejak usia dini. Dari kajian rational decision making theory, pilihan menjadi pelacur adalah pilihan rational (Murray, 1991).

Mengenai praktek prostitusi atau pelacuran di Aceh ada anggota masyarakat yang mengatakan, siapa bilang tidak ada prostitusi di Aceh? Kondisi ini sangat dimemungkinkan, karena selama ini, ketika Aceh tidak memiliki lokalisasi prostitusi yang resmi, tetapi banyak tersebar tempat prostitusi terselubung. Karena praktek prostitusi (pelacuran) di Aceh terlaksana secara terselubung, maka sulit bagi kita untuk mendapatkan angka yang valid tentang kuantitas para pelacur di negeri ini, baik pelacur laki-laki, maupun pelacur yang perempuan. Walau di tabloid KONTRAS Nomor : 526| Tahun XI 28 Januari - 3 Februari 2010 mengutip data dari YDR ada sekitar 500 PSK di Aceh. Bila ini benar, maka kesimpulan kita sementara adalah ternayata pelacuran itu memang ada dan cukup besar jumlahnya bukan? Ini baru jumlah perempuannya. Pertanyaan kita selanjutnya berapa pula jumlah lakilaki yang selama ini menjadi penikmat seks bebas itu di Aceh? Pasti jumlahnya bisa lebih besar bukan? (Tabrani Yunis Desember 2012)

Masih mengutip tulisan Tabrani, berdasarkan pemberitaan yang dirilis oleh beberapa media local, baik surat kabar maupun tabloid, di Aceh memang tersimpan potensi prostitusi yang dilakukan oleh orang Aceh sendiri dan orang-orang yang didatangkan dari luar Aceh seperti Sumatera Utara, Riau, Palembang dan bahkan diimpor dari pulau jawa dan sebagainya. Pelakunya, bukan saja perempuan yang disebut sebagai PSK, WTS, perek, perempuan pelacur, tetapi juga laki-laki sebagai penikmat seks yang kita kenal dengan lelaki hidung belang. Jadi dengan demikian, dilihat dari aspek pelakunya, bukan saja perempuan, tetapi juga laki-laki., yang bukan saja dari kalangan remaja, tetapi juga orang tua yang sudah punya isteri dan anak. Jadi, sekali lagi bahwa pelakuknya adalah perempuan dan laki-laki. Namun dalam realitas sehari-hari, ketika kita mencoba mencari siapa biang dari prostitusi tersebut, maka perempuanlah yang selalu menjadi penyebabnya. Padahal, bila kita mau jujur, perempuan pelacur tidak akan bisa melacurkan diri, kalau tidak ada laki-laki yang mencarinya. Para perempuan pelacur membuka bisnis lacurnya, karena di situ ada si pembeli yang selalu membutuhkan seks.

Dampak Praktek Pelacuran Dari sisi kesehatan, perilaku Praktek Pelacuran bisa menimbulkan berbagai gangguan. Diantaranya, dapat menyebabkan terjangkitnya penyakit HIV/AIDS, terjadi kehamilan yang tidak diinginkan. Selain tentunya kecenderungan untuk aborsi, juga menjadi salah satu penyebab munculnya anak-anak yang tidak diinginkan. Keadaan ini juga bisa dijadikan bahan pertanyaan tentang kualitas anak tersebut, apabila ibunya sudah tidak menghendaki.

\subsection{Penyakit HIV/AIDS}

Tingginya kasus penyakit Human Immunodeficiany Virus/Acquired Immnune Deficiency Syndrome (HIV/AIDS), khususnya pada kelompok PSK akibat hubungan kelamin yang berganta-ganti Pasangan. Padahal kita ketahui sampai saat ini belum ada obat dari penyakit AIDS ini. Jika telah kena penyakit ini kita hanya menunggu waktu mati saja, karena kita sudah tidak dapat berbuat apa-apa. Semakin memprihatinkan penderita HIV/AIDS 
memberikan gambaran bahwa, cukup banyak permasalahan kesehatan reproduksi yang timbul secara fisik dan mental serta sosial.

\subsection{Aborsi}

Aborsi memiliki risiko penderitaan yang berkepanjangan terhadap kesehatan maupun keselamatan hidup seorang wanita. Tidak benar jika dikatakan bahwa seseorang yang melakukan aborsi " tidak merasakan apa-apa dan langsung boleh pulang ". Ini adalah informasi yang sangat menyesatkan bagi setiap wanita, terutama mereka yang sedang kebingungan karena tidak menginginkan kehamilan yang sudah terjadi. Resiko kesehatan terhadap wanita yang melakukan aborsi berisiko kesehatan dan keselamatan secara fisik dan gangguan psikologis. Dalam buku "Facts of Life" yang ditulis oleh Brian Clowes, Ph.d; Risiko kesehatan dan keselamatan fisik yang akan dihadapi seorang wanita pada saat melakukan aborsi dan setelah melakukan aborsi adalah ; a. Kematian mendadak karena pendarahan hebat. Kematian mendadak karena pembiusan yang gagal. b. Kematian secara lambat akibat infeksi serius disekitar kandungan. Rahim yang sobek (Uterine Perforation). c. Kerusakan leher rahim (Cervical Lacerations) yang akan menyebabkan cacat pada anak berikutnya. d. Kanker payudara (karena ketidakseimbangan hormon estrogen pada wanita),Kanker indung telur (Ovarian Cancer). Kanker leher rahim (Cervical Cancer). Kanker hati (Liver Cancer). e. Kelainan pada placenta/ari-ari (Placenta Previa) yang akan menyebabkan cacat pada anak berikutnya dan pendarahan hebat pada saat kehamilan berikutnya. f. Menjadi mandul/tidak mampu memiliki keturunan lagi ( Ectopic Pregnancy). g. Infeksi rongga panggul (Pelvic Inflammatory Disease).Infeksi pada lapisan rahim (Endometriosis) Proses aborsi bukan saja suatu proses yang memiliki resiko tinggi dari segi kesehatan dan keselamatan seorang wanita secara fisik, tetapi juga memiliki dampak yang sangat hebat terhadap keadaan mental seorang wanita. Gejala ini dikenal dalam dunia psikologi sebagai "Post-Abortion Syndrome" (Sindrom Paska-Aborsi) atau PAS. Gejalagejala ini dicatat dalam " Psychological Reactions Reported After Abortion" di dalam penerbitan The Post-Abortion Review. (Lian Lubis : 2010)

\section{Metode Penelitian}

Adapun metodologi yang digunakan adalah menggunakan pendekatan kualitatif dengan menganalisis data yang bersumber dari data primer dan sekunder dengan teknik pengumpulannya mengunakan teknik obeservasi, interview yang mendalam, dokumentasi dan trianggulasi data bila diperlukan, dengan teknik analisisnya melalui display data, mereduksi data, verifikasi data, penarikan kesimpulan berdasarkan semua data yang diperoleh peneliti dilapangan dengan pemahaman induktif dan disesuai kaedah metodelogi penelitian kualitatif.

\section{Pembahasan}

Sejak awal penelitian ini pada dasarnya mengkaji secara eksplisit tentang peredaran Narkoba dan Praktek Pelacuran yang ada di Aceh dalam beberapa tahun terakhir. Alasan yang membuat tim tertarik untuk mengkaji hal tersebut sangat sederhana.

Yang pertama adalah dari internal Aceh, penawaran ada karena adanya permintaan. Mengkaji masalah ini membutuhkan analisis mendalam di mulai dari masyarakat lapisan terbawah sampai yang teratas, mengapa terjadi permintaan dari masyarakat Aceh dari berbagai lapisan, terhadap konsumsi Narkoba dan Praktek Pelacuran? Lapisan mana yang memiliki kecenderungan untuk mengonsumsi Narkoba dan melakukan Praktek Pelacuran? 
Apakah hanya lapisan atas ataukah juga sampai ke lapisan bawah? Narkoba jenis apa yang dikonsumsi oleh masing-masing lapisan? Berapa usia, pekerjaan dari para pengguna Narkoba dan begitu juga halnya yang berkaitan dengan Praktek Pelacurannya ? Analisis mendalam terkait pertanyaan-pertanyaan tersebut diperlukan untuk menarik kesimpulan factor internal yang menjadi permintaan supply Narkoba dan Praktek Pelacuran itu sendiri. Hal ini penting untuk kemudian dibandingkan dengan analisis berikutnya.

Yang kedua adalah factor eksternal. Dalam hal ini pada dasarnya tim peneliti akan menganalisis dari mana saja supply Narkoba dan Praktek Pelacuran yang datang ke Aceh maupun yang keluar dari Aceh. Supply masuk dan keluar tentu saja pada dasarnya samasama berbahaya. Jika supply Narkoba dan Praktek Pelacuran masuk ke Aceh tentu akan membahayakan generasi muda Aceh, jika supply Narkoba dan Praktek Pelacuran keluar dari Aceh maka bisa dipastikan Narkoba dan Praktek Pelacuran tersebut diproduksi dan dilakukan di Aceh. Sejauh ini Narkoba yang masih sangat memungkinkan untuk diproduksi di Aceh untuk kemudian disupply keluar hanyalah ganja. Tetapi jika ditemukan jenis-jenis Narkoba dan orang yang terlibat dalam Pelacuran disupply dari Aceh ke luar Aceh maka penting untuk semua pihak mulai mewaspadai bahwasanya para pengedar Narkoba dan Praktek Pelacuran telah mengincar lengahnya masyarakat serta pemerintah Aceh dalam menangani isu Narkoba dan Praktek Pelacuran. Hal ini juga bisa dikaitkan dengan bahaya yang dapat dihasilkan dari produksi Narkoba dan Praktek Pelacuran tersebut kepada generasi muda karena selalu ada kemungkinan untuk memasarkan Narkoba dan Praktek Pelacuran tersebut baik di luar maupun di dalam Aceh demi memenuhi keuntungan ekonomis yang didapat dari setiap transaksi Narkoba dan Praktek Pelacuran

Yang ketiga adalah peran pemerintah. Analisis mendalam perlu dilaksanakan terhadap kebijakan-kebijakan konkrit yang telah dibuat pemerintah dalam menanggulangi masalah peredaran Narkoba dan Praktek Pelacuran. Tidak hanya sampai disitu saja tetapi juga implementasi konkrit dari kebijakan-kebijakan tersebut yang terjadi di lapangan. Apakah hal ini sampai ke masyarakat ataukah hanya sebatas pembuatan kebijakan yang nihil implementasi lapangannya? Dalam kategori ini, tim juga akan menganalisis peran dari perguruan tinggi sebagai garda terdepan pendidikan dalam menyelamatkan SDM negara dari bahaya Narkoba dan Praktek Pelacuran. Apa saja preventive action yang telah dilakukan oleh perguruan tinggi dalam menyadarkan masyarakat, khususnya mahasiswa di kawasan kampus, dari bahaya Narkoba dan Praktek Pelacuran yang dapat menjerat generasi muda Aceh. Pemerintah tentunya harus menggandeng pihak-pihak yang memiliki concern yang sama seperti kepolisian, civil society dan organisasi-organisasi secara nyata bergerak dalam bidang pemberantasan Narkoba dan Praktek Pelacuran. Kerjasama yang dijalin antar pihak-pihak tersebut penting dalam pemberantasan Narkoba dan Praktek Pelacuran sampai pada akarakarnya.

Kajian ini mengambil data dari beberapa kota antara lain: Kota Lhokseumawe, Takengon, Langsa, Meulaboh dan Banda Aceh. Data yang peneliti dapat kemudian akan dikumpulkan untuk mengambil suatu kesimpulan berdasarkan tiga factor yang akan dianalisis oleh tim. Tim peneliti juga akan mencoba untuk membuat rekomendasi kebijakan yang dapat diambil oleh pemerintah terkait upaya menyelamatkan generasi muda dengan cara memutus rantai peredaran Narkoba dan Praktek Pelacuran.

\section{Kesimpulan}

Penelitian singkat ini mengkaji secara eksplisit tentang peredaran Narkoba dan Praktek Pelacuran yang ada di Aceh dalam beberapa tahun terakhir baik secara internal maupun eksternal, pada lapisan mana yang memiliki kecenderungan untuk mengonsumsi Narkoba dan 
melakukan Praktek Pelacuran? Apakah hanya lapisan atas ataukah juga sampai ke lapisan bawah? Narkoba jenis apa yang dikonsumsi oleh masing-masing lapisan? Berapa usia, pekerjaan dari para pengguna Narkoba dan begitu juga halnya yang berkaitan dengan Praktek Pelacurannya, sejauh mana peran pemerintah yang telah dijalankan dengan berbagai kebijakannya dalam memberantras Narkoba praktek Pelacuran di Aceh, apakah terimplementasi dengan baik ataukah hanya sebatas kebijakan yang nihil implementasinya di lapangan, di samping itu penelitian ini menganalisis juga peran dari perguruan tinggi sebagai garda terdepan pendidikan dalam menyelamatkan SDM negara dari bahaya Narkoba dan Praktek Pelacuran.

Apa saja preventive action yang telah dilakukan oleh perguruan tinggi dalam menyadarkan masyarakat, khususnya mahasiswa di kawasan kampus, dari bahaya Narkoba dan Praktek Pelacuran yang dapat menjerat generasi muda Aceh. Bagaimanakah Peran Pemerintah Aceh selama ini apakah telah menjalankan sinergisitas kerja dengan keuatan lainya tentunya harus menggandeng pihak-pihak yang memiliki concern yang sama seperti kepolisian, civil society dan organisasi-organisasi secara nyata bergerak dalam bidang pemberantasan Narkoba dan Praktek Pelacuran. Kerjasama dan sinergisitas kerja yang dijalin antar pihak-pihak tersebut penting dalam pemberantasan Narkoba dan Praktek Pelacuran sampai pada akar-akarnya.

Data lapangan yang diperoleh di lima daerah Kabupaten /Kota di Aceh sudah dapat mewakili sebagai sampel seluruh daerah yang ada di Aceh. Adapun kota yang dijadikan referensi data primer adalah Kota Lhokseumawe, Banda Aceh, Meulaboh, Takengon, dan Kota Langsa dengan asumsi Lhokseumawe dan Langsa mewakili Aceh Pesisir, Banda Aceh Pusat Pemerintahan Aceh, Meulaboh mewakili daerah Aceh bagian barat selatan dan Takengon mewakili daerah Aceh bagian tengan. Makin jelas bahwa Narkoba dan Praktek Pelacuran telah menjadi masalah Aceh yang harus diatasi dan dtanggulangi oleh pemerintah dan masyarakat secara berkesinambungan dan simultan serta komprehensif agar tidak bertambah meluas di masa depan.

\section{Daftar Pustaka}

Rahardjo, Satjipto. "Hukum Progressif (Penjelasan Suatu Gagasan)", Makalah disampaikan pada acara Jumpa Alumni Program Doktor Ilmu Hukum Undip Semarang, tanggal 4 September 2004. Dalam Bernard L. Tanya, Hukum dalam Ruang Sosial. (Yogyakarta: Genta Publishing, 2011).

-----------, Budaya Hukum dalam Permasalahan Hukum di Indonesia, Ceramah Seminar Hukum Nasional ke IV, Badan Pembinaan Hukum Nasional, Jakarta, 1979.

Rijadi, Prasetijo. "Pembangunan Hukum Penataan Ruang dalam Konteks Konsep Kota Berkelanjutan: Studi Hukum Penataan Ruang di Kota Surabaya.” Disertasi. (Semarang: Program Doktor Ilmu Hukum Universitas Diponegoro, 2004).

Reid, Anthony. "The Contest for North Sumatera, the Netherlands and Britain 1858-1898." Oxford University Press. 1969. Diterjemahkan oleh Masri Maris, Asal Mula Konflik Aceh, Dari Perebutan Pantai Timur Sumatera Hingga Akhir Kerajaan Aceh ke-19. (Jakarta: Yayasan Obor Indonesia, edisi kedua 2007).

Syafa'at, Rachmad. Rekonstruksi Politik Hukum Pangan, dari Ketahanan Pangan ke Kedaulatan Pangan, (Malang: UB Press, 2013).

Syafa'at, Rachmad. 'Rekonstruksi Politik Hukum Ketahanan Pangan Berbasis Pada Sistem Kearifan Lokal (Studi Kasus Dinamika Perlindungan Hukum Hak Masyarakat Adat Tengger Dalam menuju Kedaulatan Pangan).” Disertasi. (Semarang: Program Doktor Ilmu Hukum Universitas diponegoro, 2011). 
Syafa'at, Rachmad. "Kearifan lingkungan Masyarakat Adat dalam Pengelolaan Sumber Daya Alam Berkelanjutan: Analisis Kasus Masyarakat Adat Baduy dalam Konteks Pelaksanaan Otonomi Daerah.” Dalam Syafa'at, Rachmad, et.al. Negara, Masyarakat Adat dan Kearifan Lokal. (Malang: In-TRANS Publishing, 2008).

Syaukani, Imam dan A. Ahsin Thohari. Dasar-dasar Politik Hukum, cet. Ke-8, (Jakarta: Rajawali Press, 2012). 